\title{
Use of amiloride as a potassium conserving agent in severe cardiac disease
}

\author{
C. Davidson ${ }^{1}$ and I. M. Gillebrand ${ }^{2}$ \\ From the Department of Cardiology and Radioisotopes, St. Bartholomew's Hospital, London
}

Amiloride was used as a potassium conserving agent in 24 cardiac patients requiring large doses of frusemide, and the changes in plasma and total exchangeable potassium were studied over a 6-month period. Plasma potassium rose ( $+0.4 \mathrm{I} \mathrm{mEq} / \mathrm{l}$.; $P<0.0 \mathrm{I})$ and this rise was sustained throughout. Four patients had persistent hypokalaemia, but hyperkalaemia was not found. The total exchangeable potassium initially rose $(+320 \mathrm{mEq}$; $P<0.02)$ over the first 3 months but fell in the last 3 months $(-198 \mathrm{mEq} ; P<0.01)$ so that at 6 months no overall change had occurred. Amiloride is thus suitable for use with frusemide as an antikaliuretic agent, provided adequate dietary intake of potassium is ensured.

Potassium depletion, as estimated by total exchangeable potassium (TEK), is common in patients with severe cardiac disease, and is thought to be due either to a fall in intracellular potassium concentration (Flear et al., 1966) or to the loss of lean tissue accompanying cardiac cachexia (White et al., 1969). Diuretic treatment in heart failure is frequently complicated by hypokalaemia with the associated hazards of digitalis toxicity, but in addition diuretics may directly contribute to overall potassium depletion (Lockey et al., 1966). Potassium supplements generally prevent hypokalaemia but have not been shown to prevent a negative potassium balance, particularly when the more potent diuretics are used.

Amiloride, a recently introduced potassiumsparing diuretic, has been shown to prevent hypokalaemia and reduce urinary potassium loss when used with thiazides (Gombos, Freis, and Moghadam, 1966; Paterson, Dollery, and Haslam, 1968; Antcliff et al., 1971), ethacrynic acid (Singh et al., 1967; Yamada and Reynolds, 1970), and frusemide (Singh, Hurley, and North, 1969). This study reports the effects of replacing potassium supplements by amiloride in cardiac patients requiring treatment with frusemide. The changes in both plasma potassium and total exchangeable potassium were measured over a 6-month period.

Received II October 1972.

${ }^{1}$ Present address: Department of Medicine, Leeds Gene ra Infirmary.

${ }^{2}$ Present address: Institute of Cardiology, London W.r.

\section{Patients and methods}

\section{Patients}

Clinical details of the 24 patients studied are summarized in Table $\mathrm{r}$. The patients selected required at least $80 \mathrm{mg}$ frusemide daily as maintenance diuretic therapy, and had been established on their current regimen for at least two months before entering the trial. Potassium supplements $(24-48 \mathrm{mEq} /$ day) were stopped and replaced by amiloride $20 \mathrm{mg} / \mathrm{day}$, but diet and other therapy were not altered. Patients were fully informed of the objectives of the trial, and warned to report any adverse reactions immediately; withdrawal from the trial was considered necessary if there was clinical deterioration, severe hypokalaemia, or a rise in blood urea to greater than $100 \mathrm{mg} / 100 \mathrm{ml}$.

\section{Clinical methods}

The patients attended as outpatients, initially each week, but subsequently every 2 to 3 weeks over the course of 6 months. Plasma electrolytes were determined on each attendance and total exchangeable potassium measured initially and after 3 and 6 months. Blood was taken from an unoccluded arm vein with full aseptic precautions, and plasma was separated by centrifuge within an hour. Total exchangeable potassium was estimated by the isotope dilution method (Corsa et al., 1950) using ${ }^{43} \mathrm{~K}$. Potassium supplements were omitted for $\mathbf{2 4}$ hours before the initial estimation but it was not felt justified to discontinue diuretic therapy and this was continued as usual during the test period. $20-40 \mu \mathrm{Ci}^{43} \mathrm{~K}$ in potassium chloride were given intravenously and the specific activity of urine samples passed between 22 to 24 and 24 to 26 hours was measured. Retention of the administered dose over the first 22 hours was found to be relatively constant in the first 25 estimations $(96 \cdot 9 \%$, SD I.2\%) and for convenience of collection was subsequently 
TABLE I Clinical data

\begin{tabular}{|c|c|c|c|c|c|c|c|}
\hline $\begin{array}{l}\text { Case } \\
\text { No. }\end{array}$ & $\begin{array}{l}\text { Age } \\
(y r)\end{array}$ & $\begin{array}{l}H t \\
(\mathrm{~cm})\end{array}$ & $\begin{array}{l}W t \\
(k g)\end{array}$ & 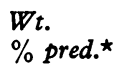 & Diagnosis & $\begin{array}{l}\text { Diuretic } \\
\text { treatment }\end{array}$ & $\begin{array}{l}\text { Duration of } \\
\text { treatment }(y r)\end{array}$ \\
\hline \multicolumn{8}{|l|}{ Male } \\
\hline I & 36 & $\mathbf{1 7 7}$ & 52 & $74 \cdot 5$ & Cardiomyopathy & F 160 & 2 \\
\hline 2 & 34 & 183 & $67 \cdot 5$ & $82 \cdot 5$ & Aortic valve replacement; mitral incompetence & F 120 & 2 \\
\hline 3 & 48 & $171 \cdot 5$ & $66 \cdot 25$ & 88 & Mitral stenosis; aortic incompetence & F I60 & 2 \\
\hline \multicolumn{8}{|c|}{ Female } \\
\hline 4 & $5 \mathrm{I}$ & 160 & $68 \cdot 75$ & 108 & Mixed mitral valve disease & F 80 & 7 \\
\hline 5 & 67 & 158 & & $94: 5$ & Mixed mitral valve disease & F I20 & 5 \\
\hline 6 & 55 & 166 & $62 \cdot 25$ & 91 & $\begin{array}{l}\text { Mixed mitral valve disease; systemic } \\
\text { hypertension }\end{array}$ & F 160 & 4 \\
\hline 7 & 56 & 153.5 & $47 \cdot 25$ & $79 \cdot 8$ & Mixed mitral valve disease & F 120 & 6 \\
\hline 8 & 68 & 163 & 86.5 & I3I & Mitral incompetence; ischaemic heart disease & F 80 & 3 \\
\hline 9 & 54 & 158.5 & 64 & 103.5 & Mitral incompetence & F 80 & 4 \\
\hline 10 & 60 & 164 & $64 \cdot 5$ & 95 & $\begin{array}{l}\text { Mixed mitral valve disease; pulmonary } \\
\text { hypertension }\end{array}$ & F 160 & 5 \\
\hline II & 51 & 156 & 67 & 105 & $\begin{array}{l}\text { Mixed mitral valve disease; AVD; pulmonary } \\
\text { hypertension }\end{array}$ & F 160 & 7 \\
\hline 12 & 47 & 154.5 & 59 & 100 & Mixed mitral valve disease & F 80 & 9 \\
\hline 13 & $5 I$ & 156 & 50 & $82 \cdot 7$ & Mixed mitral valve disease & F 80 & 0.5 \\
\hline 14 & 57 & 160 & $51 \cdot 5$ & 97 & Mixed mitral valve disease & F 160 & 5 \\
\hline 15 & 58 & $159 \cdot 5$ & 44 & 69 & Mitral incompetence; systemic hypertension & F 160 & 2 \\
\hline I6 & 38 & 160 & 79 & $134 \cdot 5$ & Mitral valve replacement & F I60 & 0.5 \\
\hline 17 & 49 & 157 & 60 & 100 & Mixed mitral valve disease & F 80 & 4 \\
\hline 18 & 57 & 159.5 & $56 \cdot 5$ & $88 \cdot 7$ & $\begin{array}{l}\text { Aortic valve replacement; mixed mitral valve } \\
\text { disease; TVD }\end{array}$ & F 160 & 7 \\
\hline 19 & 46 & 153.5 & 47 & $80 \cdot 7$ & Mixed mitral valve disease; TVD & F 160 & 6 \\
\hline 20 & 49 & 167 & 75 & II2 & Mixed mitral valve disease & F 80 & 3 \\
\hline 21 & 54 & I5O & 45 & 78 & $\begin{array}{l}\text { Mixed mitral valve disease; pulmonary } \\
\text { hypertension }\end{array}$ & F 160 & 7 \\
\hline 22 & 58 & 166 & 60 & 88 & AVD; mixed mitral valve disease & F 120 & 5 \\
\hline 23 & 49 & 156.5 & 50.5 & 83.5 & Mixed mitral valve disease; TVD & F 80 & 6 \\
\hline 24 & 46 & $164 \cdot 5$ & 58 & $89 \cdot 2$ & AVD; mixed mitral valve disease & F 80 & 3 \\
\hline
\end{tabular}

* Weight predicted from Society of Actuaries Build and Blood Pressure Study (1959).

AVD, aortic valve disease; TVD, tricuspid valve disease.

assumed at this figure. The total exchangeable potassium was calculated as the mean of the two urine samples, the average difference between the two estimates being 6.6 per cent, comparable with previous data (Staffurth, I96I).

\section{Analytical methods}

Plasma electrolytes were measured on an SMA 6/60 autoanalyser (between batch coefficient of variation $\mathrm{I} \cdot 67 \%$ ); and urinary potassium concentration on an I.L. I43 flame photometer. Radioactivity of the urine was measured in a Philips automatic well counter, counting $5 \mathrm{ml}$ aliquots from each specimen for 20 minutes and comparing activity with a standard prepared from the solution originally administered. Dietary assessment was made by one observer using the method of McCance and Widdowson (1967). Statistical analysis was by Student's ' $t$ ' test on paired data.

\section{Results}

\section{Clinical effects}

Amiloride was generally well tolerated, and most patients found it easier to take than potassium supplements. A diuresis was observed in most subjects with a weight loss of $0.5-3 \mathrm{~kg}$ in the first week of treatment but over the ensuing weeks the weight was regained, and at the end of the trial period did not differ from the original value. The only significant side effect was an alteration in taste and nausea often persisting many hours after taking the tablets, and in 3 patients the drug was discontinued for this reason. One patient (Case II, see below) was withdrawn from the study because of electrolyte disturbance, but no alteration in diuretic regimen was required in any other patient on clinical grounds, and digoxin toxicity was not observed. Dietary potassium intake, estimated in Cases I to 14 , was found to be low in 5 cases (less than $60 \mathrm{mEq} /$ day), but this did not appear to be directly related to low plasma potassium or total exchangeable potassium.

\section{Plasma electrolytes}

The overall effect of amiloride on electrolytes is summarized in Table 2 ; there was a small but sig- 
TABLE 2 Mean plasma electrolytes and blood urea before and during treatment with amiloride

\begin{tabular}{|c|c|c|c|c|c|}
\hline & $N a^{+}(m E q / l)$. & $K^{+}$ & $\mathrm{Cl}^{-}$ & $\mathrm{HCO}_{3}{ }^{-}$ & Urea $(\mathrm{mg} / \mathrm{IOO} \mathrm{ml})$ \\
\hline $\begin{array}{l}\text { Before treatment } \\
\text { Amiloride } \\
\text { SD of difference } \\
\mathbf{P}\end{array}$ & $\begin{array}{l}\text { I39.46 } \\
\text { I38.80 } \\
2.48 \\
N S\end{array}$ & $\begin{array}{r}3.54 \\
3.95 \\
0.51 \\
<0.01\end{array}$ & $\begin{array}{l}97 \cdot 08 \\
97 \cdot 04 \\
2 \cdot 40 \\
\text { NS }\end{array}$ & $\begin{array}{l}28 \cdot 70 \\
28 \cdot 20 \\
I \cdot 91 \\
\text { NS }\end{array}$ & $\begin{array}{l}38 \cdot 50 \\
42 \cdot 00 \\
10 \cdot 15 \\
\text { NS }\end{array}$ \\
\hline
\end{tabular}

nificant increase in plasma potassium (mean $+0.4 \mathrm{I}$ $\mathrm{mEq} / \mathrm{l} ., \mathrm{P}<0.01$ ) but no change in any of the other parameters measured. This increase in potassium was present after one week of treatment, and persisted without any significant change for the remainder of the study. The initial potassium readings were lower than expected (mean $3.54 \mathrm{mEq} / \mathrm{l}$.), probably because of the care taken in venepuncture, avoiding factors which may give falsely high readings in routine measurements. Details of individual potassium levels are shown in Tables 3 and $4 ;$ in 4 patients (Cases 5, 7, II, and I7) plasma potassium remained less than $3.7 \mathrm{mEq} / \mathrm{l}$. throughout, though there was no evidence of clinical deterioration or digoxin intoxication. In one patient (Case II), however, the potassium fell to less than $3.0 \mathrm{mEq} / \mathrm{l}$. and the blood urea rose to $105 \mathrm{mg} / 100 \mathrm{ml}$, so that amiloride had to be discontinued after 3 months' treatment. The small rise in blood urea observed in most patients was not significant; the blood urea did not rise above $70 \mathrm{mg} / 100 \mathrm{ml}$ in any other patient.

\section{Total exchangeable potassium}

The patients studied fell into two groups; the first (group A) in whom measurements were made before and during treatment with amiloride, and the second (group B) in whom measurements were obtained only when therapy had been established. Details of group A are shown in Table 3. A significant increase in total exchangeable potassium occurred in the first 3 months of treatment $(P<0.02)$, but over a further 3 months there was a fall in 6 of the 9 patients, and the total exchangeable potassium at 6 months did not differ significantly from the original value. In group B (Table 4 ) there was no significant change between the third and the sixth month of treatment, but when the figures of the two groups were combined a significant fall in total exchangeable potassium was found over this period $(P<0.01)$. These findings are summarized in Table 5 from which it is concluded that though treatment with amiloride was associated with an initial rise in total exchangeable potassium, this was not sustained over a longer period of study.

TABLE 3 Group A: plasma potassium and TEK before and during six months treatment with amiloride

\begin{tabular}{|c|c|c|c|c|c|c|c|}
\hline \multirow[t]{2}{*}{$\begin{array}{l}\text { Case } \\
\text { No. }\end{array}$} & \multicolumn{3}{|c|}{ Plasma $K^{+}(m E q / l)}$. & \multicolumn{2}{|c|}{$\begin{array}{l}\text { Total exchangeable } \\
\text { potassium (mEq) }\end{array}$} & \multirow{2}{*}{$\begin{array}{l}\Delta \text { Total } \\
\text { exchangeable } \\
\text { potassium } \\
3 \text { mth } \dagger\end{array}$} & \multirow{2}{*}{$\begin{array}{l}\Delta \text { Total } \\
\text { exchangeable } \\
\text { potassium } \\
6 \mathrm{mth}\end{array}$} \\
\hline & 0 & 3 & $6 \mathrm{mth}$ & $\begin{array}{l}\text { Before } \\
\text { treatment }\end{array}$ & $\%$ pred.* & & \\
\hline I & $3 \cdot 8$ & $4 \cdot 4$ & 4.9 & 2120 & $66 \cdot 5$ & -100 & -190 \\
\hline 2 & 3.9 & 4.5 & $4 \cdot 2$ & 2680 & 74 & +670 & +450 \\
\hline 4 & $3 \cdot 8$ & $4 \cdot 2$ & $4 \cdot I$ & 2219 & 94 & +510 & +315 \\
\hline 5 & $2 \cdot 8$ & 3.4 & 3.4 & 2210 & - & +270 & -360 \\
\hline 6 & $4 \cdot 3$ & 4.0 & $3 \cdot 8$ & 2450 & 98 & +415 & -225 \\
\hline 7 & $2 \cdot 3$ & $3 \cdot I$ & 3.4 & 1700 & 79 & +105 & -15 \\
\hline 8 & $3 \cdot 9$ & $4 \cdot 2$ & $4 \cdot I$ & 2120 & - & -290 & -3 \\
\hline 9 & 4.9 & 4.7 & $4 \cdot 5$ & 2070 & 90 & +590 & +60 \\
\hline 10 & $3 \cdot 0$ & 3.8 & - & 2020 & 82 & +210 & - \\
\hline II & $2 \cdot 5$ & $3 \cdot 2$ & - & 2100 & 94 & +270 & - \\
\hline 12 & $3 \cdot 1$ & $3 \cdot 2$ & $4 \cdot 0$ & 2380 & 106.5 & -50 & -140 \\
\hline 13 & $3 \cdot 3$ & $4 \cdot 3$ & 3.9 & 1960 & 86.5 & +390 & -130 \\
\hline 14 & $3 \cdot 6$ & $4 \cdot I$ & - & 2025 & 93 & +1200 & - \\
\hline
\end{tabular}

* Predicted values for total exchangeable potassium obtained from Flear et al. (1966).

t $\Delta$ total exchangeable potassium indicates change in total exchangeable potassium compared to the initial reading. 
TABLE 4 Group B: effect of amiloride on plasma potassium and total exchangeable potassium in patients in whom initial total exchangeable potassium was not obtainable

\begin{tabular}{|c|c|c|c|c|c|}
\hline \multirow[t]{2}{*}{$\begin{array}{l}\text { Case } \\
\text { No. }\end{array}$} & \multicolumn{3}{|c|}{ Plasma $K^{+}(m E q / l)}$. & \multirow{2}{*}{$\begin{array}{l}\text { Total } \\
\text { exchangeable } \\
\text { potassium } \\
\text { (mEq) } 3 \text { mth } \\
\text { treatment }\end{array}$} & \multirow{2}{*}{$\begin{array}{l}\Delta \text { Total } \\
\text { exchangeable } \\
\text { potassium } \\
6 \text { mth } \\
\text { treatment }\end{array}$} \\
\hline & $o m t h$ & $3 m t h$ & $6 m t h$ & & \\
\hline 3 & $3 \cdot 7$ & 4.4 & 4.9 & 2625 & +95 \\
\hline 15 & $3 \cdot 3$ & $3 \cdot 8$ & 40 & 1850 & -40 \\
\hline 16 & 3.5 & $4 \cdot 6$ & 3.9 & 2362 & \\
\hline 17 & 3.5 & $3 \cdot I$ & $3 \cdot 4$ & 2795 & -225 \\
\hline 18 & $3 \cdot 6$ & $3 \cdot 8$ & $4 \cdot I$ & 2120 & +130 \\
\hline 19 & $3 \cdot 7$ & $3 \cdot 8$ & $3 \cdot 7$ & 1700 & +225 \\
\hline 20 & 4.5 & 3.5 & 4.4 & 3190 & +85 \\
\hline $2 I$ & 3.9 & $3 \cdot 9$ & $3 \cdot 8$ & 2045 & -150 \\
\hline 22 & $3 \cdot 3$ & $4 \cdot 2$ & $3 \cdot 6$ & 2150 & -460 \\
\hline 23 & 3.7 & $4 \cdot 3$ & $4 \cdot 2$ & 2515 & -275 \\
\hline 24 & $3 \cdot 9$ & $3 \cdot 7$ & - & 1995 & \\
\hline
\end{tabular}

* $\Delta$ total exchangeable potassium indicates change in total exchangeable potassium compared to reading at 3 months.

TABLE 5 Effect of amiloride on total exchangeable potassium in groups $A$ and $B$

$\Delta$ Total exchangeable potassium ${ }^{\star}$

\begin{tabular}{lccc} 
& $0-3 m t h$ & $0-6 m t h$ & $3-6 m t h$ \\
\hline Mean difference & $+320 \cdot 0$ & -26.0 & -198.5 \\
SD of difference & 384.1 & $259 \cdot 1$ & 266.6 \\
$\mathrm{P}$ & $<0.02$ & $\mathrm{NS}$ & $<0.01$ \\
& $\mathrm{n}=13$ & $\mathrm{n}=9$ & $\mathrm{n}=18$
\end{tabular}

* $\Delta$ total exchangeable potassium is the change in total exchangeable potassium over the periods indicated.

\section{Discussion}

The place of potassium conserving agents in diuretic therapy has not been clearly established. Except in occasional situations their diuretic action is too weak for use alone, and dangerous hyperkalaemia may occur (Yamada and Reynolds, 1970). They are therefore generally used in combination with potassium-losing diuretics, and on theoretical grounds seem more suitable for maintaining potassium balance than potassium supplements alone. However, their effective use requires an adequate potassium intake which may not always be present in patients with severe heart disease. In this study 5 of I4 patients had a low dietary potassium, and similar findings have been reported in geriatric patients (Dall and Gardiner, I97I) and in patients with liver disease (Senewiratne and Sherlock, I968), either from anorexia or a poor choice of food. As stressed by the latter authors, simple dietary advice can greatly augment potassium intake, and is essential in long-term diuretic treatment, especially when potassium-conserving agents are used.

Amiloride has been shown to be an effective antikaliuretic agent when used with thiazides, ethacrynic acid, and frusemide in short-term studies, potentiating the diuresis of these drugs while reducing urinary potassium loss by up to 50 per cent. Plasma potassium generally rises, and long-term studies have confirmed that amiloride prevents the usual fall in plasma potassium accompanying thiazide treatment (Paterson, et al., 1968; McNay, MacCannell, and Oran, 1970; Antcliff et al., 1971). However, when used in combination with ethacrynic acid, this effect is less consistent and hypokalaemia may occur (Senewiratne and Sherlock, 1968; Yamada and Reynolds, 1970).

In this study the use of a standard dose of amiloride in place of potassium supplements was associated with a small but significant rise in plasma potassium in most patients, which was maintained throughout the 6-month period. The low plasma potassium levels present in 12 patients on their previous regimen suggested that the potassium supplements given were inadequate for the dose of frusemide used. Amiloride therefore seems to have been more effective in maintaining plasma potassium than conventional doses of potassium supplements in these patients. Nevertheless, hypokalaemia was found in a few patients so that continued electrolyte monitoring is essential. In two of these patients plasma potassium rose to the normal range when the dose of amiloride was increased to $40 \mathrm{mg} /$ day, and it may be that with more potent diuretics amiloride should be used in higher doses than generally recommended by the manufacturers, particularly as the most dangerous side effect, hyperkalaemia, is rarely found in combination therapy.

In addition to the effects on plasma potassium, amiloride has been shown to reverse the hypochloraemic alkalosis of diuretic treatment, probably by promoting the renal excretion of bicarbonate (Reynolds and Pelle, 1966). Though this has been confirmed with thiazides (Antcliff et al., 197I) in long-term treatment, it was less consistently found with ethacrynic acid (Yamada and Reynolds, 1970) and in the present study no significant change in plasma bicarbonate occurred, most patients remaining alkalotic. A rise in blood urea was however found in most patients, though this was not significant overall. It was not progressive or associated with any clinical deterioration and probably represents a fall in renal plasma flow consequent on the diuresis rather than any diuretic nephrotoxic action of the drug (Lieberman, Ito, and Reynolds, 1969). 
Changes in plasma potassium are known to bear little direct relation to variations in body potassium as a whole (Flear, Cooke, and Quinton, 1957), and this is evident in the present study where no overall change in total exchangeable potassium occurred despite a persistent rise in plasma potassium. The measurement of total exchangeable potassium in patients with cardiac disease is complicated by the delay in equilibration of the potassium isotope which occurs in all oedematous states (O'Meara et al., 1957). Adequate equilibration may not occur for up to 48 hours, so that the 24 -hour reading used for the convenience of the patients in this study may underestimate the absolute total exchangeable potassium by 5 to Io per cent, but still enables valid comparisons of serial changes in total exchangeable potassium to be made in each patient.

The clinical significance of the changes in total exchangeable potassium observed in the present study is not clear, particularly in the absence of any corresponding change in body weight. Its initial rise suggests that over the first 3 months a positive potassium balance was more effectively maintained than with the previous potassium supplements. The later fall in total exchangeable potassium is similar to the findings of Senewiratne and Sherlock (1968) in cirrhotic patients, and Croxson, Neutze, and John (1972) in cardiac patients. In both these studies, one-fifth of the patients failed to maintain potassium balance with amiloride; whether this represents a loss of efficacy of the drug or merely reflects the continued wasting associated with the disease itself could only be clarified by a more extensive study.

The efficacy of an antikaliuretic agent must be measured by the extent to which it maintains both plasma potassium levels and a positive potassium balance. In the first respect, amiloride compares favourably with the other potassium conserving agents, spironolactone and triamterene (Lant, Smith, and Wilson, 1969; Yamada and Reynolds, I970), but few studies are available for a comparison of the effects of these drugs on potassium balance as a whole. Most studies of potassium balance have been concerned with the use of thiazides in hypertension, and the results may not be directly applicable in the treatment of oedema. Even in this situation, the evidence that diuretics lead to a fall in total exchangeable potassium is conflicting (Anderson et al., 1971; Down et al., 1972), possibly because little attention is paid to what may be a significant variation in potassium intake. Nevertheless, McKenna et al. (I97I) found a consistent fall in patients on thiazides and were able to compare the effect of potassium supplements, spironolactone, and triamterene; the first two prevented a fall in total exchangeable potassium but triamterene did not.
In cardiac disease, the information is more limited. Potassium supplements when given in large doses (96 mEq/day) promoted a rise in total exchangeable potassium in preoperative cardiac patients (White, 1969), and this suggests that conventional doses of potassium are insufficient to maintain a satisfactory balance in patients needing a potent diuretic regimen. Spironolactone used in a similar group of patients prevented any fall in total exchangeable potassium (White, 1969), but short-term balance studies have indicated that additional potassium supplements may be necessary in some patients (Ross, 1961). The information from the present study and those of Senewiratne and Sherlock (I968) and Croxson et al. (1972) suggest that amiloride can be used as the sole anti-kaliuretic agent in the long-term treatment of patients on potent diuretics, and that it may be more effective than the potassium supplements in doses currently used.

\section{Conclusion}

Amiloride has been used successfully as the sole potassium conserving agent in the long-term treatment of patients with severe cardiac disease who required large doses of frusemide as maintenance therapy. Plasma potassium rose to the normal range in most patients, and the changes in total exchangeable potassium observed suggest that a negative potassium balance was prevented. Side effects, mainly gastrointestinal, were few, and limited treatment in 4 patients only. The initial rise in plasma potassium and total exchangeable potassium suggests that amiloride may be more effective than conventional doses of potassium supplements, but with large doses of frusemide hypokalaemia may occur and continued electrolyte monitoring is essential. A significant number of patients with cardiac disease may have a poor potassium intake, and simple dietary advice is important when large doses of diuretics are used.

We would like to thank Dr. G. W. Hayward and Dr. J. Hamer for permission to study their patients; Mr. L. R. Hawkins for advice on radioisotope technique, Mr. P. Myall for assistance in the total exchangeable potassium measurements, Miss McKay for dietary assessment, and Dr. J. Hamer for advice in the preparation of this paper.

\section{References}

Anderson, J., Godfrey, B. E., Hill, D. M., Munro-Faure, A. D., and Sheldon, J. (197I). A comparison of the effects of hydrochlorothiazide and of frusemide in the treatment of hypertensive patients. Quarterly fournal of Medicine, 40, 54I.

Antcliff, A. C., Beevers, D. G., Hamilton, M., and Harpur, J. E. (197I). The use of amiloride hydrochloride in the correction of the hypokalaemic alkalosis induced by diuretics. Postgraduate Medical fournal, 47, 644. 
Build and Blood Pressure Study (1959). Society of Actuaries, Chicago, Illinois.

Corsa, L., Olney, J. M., Steenburg, R. W., Ball, M. R., and Moore, F. D. (1950). The measurement of exchangeable potassium in man by isotope dilution. Fournal of Clinical Investigation, 29, 1280 .

Croxson, M. S., Neutze, J. M., and John, M. B. (1972). Exchangeable potassium in heart disease : long-term effects of potassium supplements and amiloride. American Heart Fournal, 84, 53.

Dall, J. L. C., and Gardiner, H. S. (197I). Dietary intake of potassium by geriatric patients. Gerontologia Clinica, 13, II9.

Down, P. F., Polak, A., Rao, R., and Mead, J. A. (1972). Fate of potassium supplements in six outpatients receiving longterm diuretics for oedematous disease. Lancet, 2, $72 \mathrm{I}$.

Flear, C. T. G., Cooke, W. T., and Quinton, A. (1957). Serum-potassium levels as an index of body content. Lancet, $1,458$.

Flear, C. T. G., Quinton, A., Carpenter, R. G., Domenet, J. G., and Sivyer, A. (I966). Exchangeable body potassium and sodium in patients in congestive heart failure. Clinica Chimica Acta, 13, r.

Gombos, E. A., Freis, E. D., and Moghadam, A. (1966). Effects of MK-870 in normal subjects and hypertensive patients. New England fournal of Medicine, 275, 1215.

Lant, A. F., Smith, A. J., and Wilson, G. M. (1969). Clinical evaluation of amiloride, a potassium-sparing diuretic. Clinical Pharmacology and Therapeutics, 10, 50.

Lieberman, F. L., Ito, S., and Reynolds, T. B. (1969). Effective plasma volume in cirrhosis with ascites. Evidence that a decreased value does not account for renal sodium retention, a spontaneous reduction in glomerular filtration rate (GFR) and a fall in GFR during drug-induced diuresis. Fournal of Clinical Investigation, 48, 975.

Lockey, E., Longmore, D. B., Ross, D. N., and Sturridge, M. F. (1966). Potassium and open-heart surgery. Lancet, I, 67 I.

McCance, R. A., and Widdowson, E. M. (1967). The composition of foods, 3 rd ed. Medical Research Council Special Report Series, No. 297.

McKenna, T. J., Donohoe, J. F., Brien, T. G., Healy, J. J., Canning, B. St. J., and Muldowney, F. P. (I97I). Potassium-sparing agents during diuretic therapy in hypertension. British Medical fournal, 2, 739.
McNay, J. L., MacCannell, K. L., and Oran, E. (1970). Potassium-retaining diuretics: electrolyte changes induced in hypertensive patients. Pharmacologia Clinica, 2, 94.

O'Meara, M. P., Birkenfeld, L. W., Gotch, F. A., and Edelman, I. S. (1957). The equilibration of radiosodium $\left({ }^{24} \mathrm{Na}\right)$, radiopotassium $\left({ }^{42} \mathrm{~K}\right)$, and deuterium oxide $\left(\mathrm{D}_{2} \mathrm{O}\right)$ in hydropic human subjects. Fournal of Clinical Investigation, 36, 784 .

Paterson, J. W., Dollery, C. T., and Haslam, R. M. (1968). Amiloride hydrochloride in hypertensive patients. British Medical fournal, $\mathbf{1}, 422$.

Reynolds, T. B., and Pelle, H. C. (1966). Effects of a new diuretic amipramidine (MK 870) in patients with cirrhosis and ascites. Clinical Research, 14, 184.

Ross, E. J. (196I). Importance of potassium supplements during the use of spironolactone and thiazide diuretics. British Medical fournal, r, 1508.

Senewiratne, B., and Sherlock, S. (1968). Amiloride ('MK $\left.870^{\prime}\right)$ in patients with ascites due to cirrhosis of the liver. Lancet, $\mathbf{1}, \mathbf{1 2 0}$.

Singh, B. N., Hurley, P. J., and North, J. D. K. (1969). The use of amiloride in potassium depletion before cardiac surgery. American Heart fournal, 78, 22.

Singh, B. N., Richmond, D. E., Wilson, J. D., Simmonds, H. A., and North, J. D. K. (1967). Evaluation of MK 870; a new potassium-sparing diuretic. British Medical fournal, I, 143 .

Staffurth, J. S. (196I). Observations on the variability of the specific activity of potassium in the measurement of total exchangeable potassium. Clinical Science, 21, 171 .

White, R. J. (1969). The body electrolytes in heart failure and in systemic hypertension. M.D. Thesis, University of Cambridge.

White, R. J., Chamberlain, D. A., Hamer, J., McAlister, J., and Hawkins, L. A. (1969). Potassium depletion in severe heart disease. British Medical fournal, 2, 606.

Yamada, S., and Reynolds, T. B. (1970). Amiloride (MK 870), a new antikaluretic diuretic. Gastroenterology, 59, 833.

Requests for reprints to Dr. C. Davidson, Department of Medicine, The Martin Wing, The General Infirmary, Leeds LSI 3 EX. 